\title{
Ultrastructural Changes of Tobacco Cell Walls following Sequential Extraction *
}

\author{
by Vicki Baliga and William R. Morgan \\ Philip Morris Research Center, Richmond, Virginia, U.S.A.
}

\section{SUMMARY}

The role of calcium in plants has been the subject of research for many years. Calcium has been postulated to cover a wide variety of functions which have major and minor influences on the plant's metabolism. Calcium interaction with pectin has been postulated as a major source of cell wall stability, however, no direct measurements of this interaction have been made.

In this study, a sequential extraction method has been utilized to fractionate the various forms of calcium present in cured Bright and Burley tobacco. The extraction method uses water, potassium chloride, lanthanum chloride and hydrochloric acid with emphasis on the lanthanum chloride extraction which appears to preferentially replace the structural calcium. Extraction data in conjunction with light microscopy (LM) and transmission electron microscopy (TEM) data have been used to predict the role of structural calcium in the cell wall. Oxalate and calcium analyses have been made at each of the extraction steps for Bright tobacco. It is shown that the major portion of calcium extracted is not associated with oxalate except for the hydrochloric acid step. The data show that approximately $20 \%$ of the calcium is structurally related and that calcium oxalate utilizes a maximum of another $20 \%$ of the total calcium. The remaining $60 \%$ is non-structural and nonoxalate and is probably inorganic salts and salts of organic acids.

\footnotetext{
* Presented at the 36th Tobacco Chemists' Research Conference, Raleigh, North Carolina, in 1982.

Received: 15th June 1983 - accepted: 11th September 1984.
}

Combining these two techniques provides a means of obtaining quantitative information that either technique used independently could not provide. The techniques used in this study are applicable to the investigation of other plant types and may be useful in furthering the general knowledge of the role of calcium in plant materials.

\section{ZUSAMMENFASSUNG}

Seit vielen Jahren wird erforscht, welche Rolle Calcium in pflanzlichem Gewebe spielt. Es werden ihm eine ganze Reihe verschiedenartiger Funktionen und über diese eine mehr oder weniger starke Beeinflussung des Stoffwechsels der Pflanze zugeschrieben. Die Festigkeit der Zellwand wird vor allem auf eine Wechselwirkung zwischen Calcium und Pektin zurückgeführt, wenngleich diese direkt noch nicht gemessen wurde.

Die verschiedenen Formen von Calcium, die in getrocknetem Virginia- und Burley-Tabak enthalten sind, wurden in der vorliegenden Untersuchung mit Hilfe sequentieller Extraktion fraktioniert. Als Extraktionsmittel dienten Wasser, Kaliumchlorid, Lanthanchlorid und Salzsäure, wobei das Schwergewicht auf der Extraktion mit Lanthanchlorid lag, das vorzugsweise das in der Zellwand eingelagerte Calcium zu ersetzen scheint. Durch Auswertung der Extraktionsbefunde unter Einsatz von Lichtmikroskopie (LM) und Transmissionselektronenmikroskopie (TEM) konnte ermittelt werden, welche Funktion das strukturgebundene Calcium in der Zellwand hat. Bei Virginia-Tabak wurden nach jeder Extraktion Calcium und Oxalat bestimmt. Es zeigte sich, daß außer bei der Salzsäureextraktion der 
größte Teil des extrahierten Calciums nicht an Oxalat gebunden ist. Aus den Befunden geht hervor, daß ungefähr $20 \%$ des Gesamtcalciums in der Zellwand eingelagert sind und daß Calciumoxalat höchstens weitere $20 \%$ ausmacht. $\mathrm{Da}$ das restliche Calcium $(60 \%)$ nicht als Oxalat vorkommt und auch nicht strukturgebunden ist, handelt es sich vermutlich um Salze anorganischer und organischer Sãuren.

Die Kombination der Extraktion mit der Mikroskopie führte in quantitativer Hinsicht zu Ergebnissen, die jede der Techniken alleine nicht hätte erbringen kōnnen. Die beschriebene Methodik ist auch bei der Untersuchung anderer Pflanzenarten anwendbar und könnte allgemein zur Erweiterung der Kenntnisse über das Calcium in Pflanzen von Nutzen sein.

\section{RÉSUMÉ}

Il y a de nombreuses années que l'on cherche à déterminer le rôle joué par le calcium dans les tissus végétaux. On attribue à cet ćlément les fonctions les plus diverses et, par là, une action plus ou moins importante sur le métabolisme des plantes. La stabilité de la membrane cellulaire semble être due essentiellement à une interaction du calcium et de la pectine, même si celle-ci n'a pu être encore mesurée directement.

Dans le cadre de la présente étude, on a réalisé, par une méthode d'extraction séquentielle, le fractionnement des différentes formes de calcium présentes dans le tabac de Virginie et le tabac Burley séchés. L'eau, le chlorure de potassium, le chlorure de lanthane et l'acide chlorhydrique servirent de produits d'extraction, l'accent étant mis sur le chlorure de lanthane, lequel semble particulièrement bien convenir pour déplacer le calcium se trouvant dans la membrane cellulaire. L'analyse des produits d'extraction au moyen de la microscopie optique (L.M) et du microscope électronique à transmission (TEM) a permis de déterminer quelle était la fonction du calcium lié à la membrane cellulaire. Dans le cas du tabac de Virginie, on dosa le calcium et l'oxalate après chaque extraction. Ceci permit de constater que, sauf dans le cas d'extraction au moyen de l'acide chlorhydrique, la majeure partie du calcium extrait n'était pas lié à l'oxalate. Les résultats obtenus montrent qu'environ $20 \%$ de la quantité totale de calcium sont liés à la membrane cellulaire et que l'oxalate de calcium représente au maximum $20 \%$ du calcium restant. Etant donné que les $60 \%$ qui restent ne sont ni présents sous forme d'oxalate, ni liés à la structure, il s'agit probablement de sels d'acides minéraux ou organiques.

Au point de vue quantitatif, la combinaison de l'extraction avec la microscopie a conduit à des résultats qu'il aurait été impossible d'atteindre en ayant recours à chacune de ces techniques séparément. La méthode décrite ici est applicable également à l'étude d'autres espèces végétales et pourrait s'avérer d'une grande utilité pour l'approfondissement général des connaissances relatives à la présence du calcium dans les plantes.

\section{INTRODUCTION}

The investigation of the role of calcium in plants has been the subject of research for many years. The postulated roles of calcium cover a variety of functions which have major and minor influences on the plant's metabolism $(1,3,4,5,6,9,10,15,16)$. It is generally agreed that calcium is necessary for the survival of the plant (16). Theories have been advanced on the interaction of calcium with pectin, indicating a major function of calcium in cell wall stability $(15,16)$. Other researchers have postulated that calcium serves mainly to precipitate oxalic acid and that the majority of the calcium is present for this purpose (6). A variety of sequential extraction schemes have been used to fractionate the various forms of calcium and, based on solubility, used to predict its function in the plant $(1,2,3,4,5,6,8$, $10,11,14)$.

It is generally agreed that calcium exists in at least two functional forms: [1] structural and [2] non-structural. Structural calcium is associated with the primary and secondary cell walls as well as the middle lamella. Nonstructural calcium is believed to be associated with: [a] membrane function, [b] enzyme systems and [c] chromosome stability (16).

Structural and non-structural calcium make up $1.5 \%$ to $3.5 \%$ of the total dry weight of the tobacco leaf depending on the variety as well as the stalk position of the leaf within that variety (16). One of the structural forms of calcium found in the leaf is associated with pectin in the middle lamella. Rasmussen (15) has suggested that calcium is the binding agent between the pectin and the cell walls. He stated that "microscopic examination of torn leaves revealed that a weak leaf separated between cells whereas a strong leaf tore through cells". He showed that $10 \mu \mathrm{m}$ thick sections of the weak leaves contained the same amount of pectin as strong leaves but less calcium, which suggested that calcium played an important role in the ability of pectin to bind the cells together.

Extraction procedures employing a variety of solvents have been used to study the different forms of calcium in the plant cell. Several assumptions have been made: [1] that water extraction removes the loosely bound ("soluble") calcium, [2] that acetic acid removes pectinassociated calcium and [3] that hydrochloric acid removes oxalate-bound calcium $(1,3,4,5,6)$. Ferguson et al. (2) have shown that because of the varying solubilities of the different forms of calcium, one cannot assume that only one form of calcium is extracted with any one specific solvent. It is probable that the waterextracted calcium contains non-structural calcium as well as some structural calcium from the cell wall, in the form of calcium pectate and/or calcium oxalate. This $\mathrm{H}_{2} \mathrm{O}$ extract contains organic acids and buffers between a $\mathrm{pH}$ of 4.5 to 5.5 depending on the variety of tobacco (13).

In this study, a sequential extraction method has been used to fractionate the various forms of calcium and, in conjunction with light microscopy (LM) and transmis- 
sion electron microscopy (TEM), has been used to predict the role of the structural calcium in the cell. Tobacco shreds were sequentially extracted with water, potassium chloride, lanthanum chloride and hydrochloric acid. We substituted lanthanum chloride for acetic acid in this study since it is known to replace calcium in biological structures (11). It is also electron dense and can be visualized using transmission electron microscopy and $\mathrm{X}$-ray mapping. Data have been acquired on both cured Bright and Burley tobacco shreds. Quantitative measurements of the amounts of calcium soluble in each of the various solvents allow for the estimation of the total structural and non-structural calcium present. Oxalate analyses were also made and correlated with the appropriate calcium fractions.

\section{MATERIALS AND MET'HODS}

\section{Extraction}

Flue-cured Bright and air-cured Burley field-grown tobacco shreds, in $1 \times 4 \mathrm{~mm}$ lengths, were sequentially extracted at room temperature by the following procedures:

1. 1 gram of tobacco was stirred in 1 liter of water for 20 minutes and filtered through a $110 \mu \mathrm{m}$ polyethylene screen. A sample of tobacco shred was air dried for transmission electron microscopy. The filtrate was analyzed for calcium by atomic absorption.

2. The remainder of the wet tobacco was stirred in 1 liter of $0.4 \% \mathrm{KCl}$ for 20 minutes and filtered as above. A sample of tobacco shred was air dried and taken for transmission electron microscopy and the filtrate was analyzed for calcium by atomic absorption.

3. The remainder of the tobacco was stirred in 1 liter of $0.4 \% \mathrm{~L}_{2} \mathrm{Cl}_{3}$ for 25 minutes and filtered as above. $\mathrm{A}$ sample of tobacco shred was air dried and taken for transmission electron microscopy and the filtrate was analyzed for calcium by atomic absorption.

4. The remainder of the tobacco was stirred in 1 liter of $2 \% \mathrm{HCl}$ for 25 minutes and filtered as above. A sample of tobacco shred was air dried and taken for transmission electron microscopy and the filtrate was analyzed for calcium using atomic absorption.

Sample preparation for light microscopy and transmission electron microscopy was as follows:

Fixation: Samples were prepared by double fixation with glutaraldehyde and osmium tetroxide. The samples were first fixed in $2 \%$ glutaraldehyde in $0.1 \mathrm{M}$ Millonig's buffer (MB) (12) for 18 hours, rinsed 3 times with $0.1 \mathrm{M}$ MB followed by the second fixation of $1 \%$ osmium tetroxide in $0.1 \mathrm{M} \mathrm{MB}$ for 2 hours. The samples were again rinsed 3 times with $0.1 \mathrm{M} \mathrm{MB}$.
Debydration: Dehydration was carried out through a graded series of ethanol - 50\%, 70\%, $85 \%, 95 \%$ (three times), $100 \%$ (three times), followed by two acetone rinses.

\section{Epoxy Infiltration: Samples were infiltrated in}

[1] 3:1 acetone to Spurr ${ }^{\star}$ epoxy solution for 2 hours,

[2] 1:1 acetone to Spurr epoxy solution for 2 hours,

[3] 1:3 acetone to Spurr epoxy solution for 2 hours and

[4] $100 \%$ Spurr solution overnight.

No accelerator was used in any of the above steps. The next morning the samples were infiltrated with $100 \%$ Spurr with accelerator for 4 hours. The samples were on a shaker during the infiltration procedure.

Embedding: The infiltrated samples were flat-embedded in firm grade Spurr. The shreds were oriented for cross-sectional sectioning.

Sectioning and Staining: $2 \mu \mathrm{m}$ thick sections were cut for light microscopy and $\sim 75 \mathrm{~nm}$ thick sections were cut for transmission electron microscopy. One percent toluidine blue mixed with an equal volume of $2.5 \%$ $\mathrm{Na}_{2} \mathrm{CO}_{3}$ was filtered and used to stain the $2 \mu \mathrm{m}$ thick sections for light microscopy. Six percent aqueous uranyl acetate and $2 \%$ lead citrate were used to stain the thin sections for transmission electron microscopy.

\section{Oxalate Analysis}

Oxalate analysis was performed on tobacco following each extraction step. Tobacco was extracted with sulfuric acid in absolute methanol which simultaneously methylated the oxalate. The methyl ester was extracted into chloroform and analyzed by gas chromatography. This procedure follows the method of Harvey, Hale and Ikeda (7).

\section{Atomic Absorption}

Atomic absorption analysis was performed on a PerkinElmer Model 403 atomic absorption spectrophotometer. Instrument conditions consisted of a calcium hollow cathode lamp, air-acetylene flame, and a monochromator setting of $422.7 \mathrm{~nm}$. Absorption data for the sample solutions were compared to standard curves, determined from measurements made on known solutions of calcium prepared in the same matrix as the sample, in order to determine the concentrations of calcium present.

\section{RESULTS AND DISCUSSION}

The ultrastructure of unextracted cured tobacco shreds is shown in Figure 1. The epidermal cells had a geomet-

\footnotetext{
"Polysciences, Inc., Warrington, Pa, U.S.A.
} 
Figure 1.

Unextracted control. Note intact cell walls and open epidermal $(E)$ and mesophyll $(M)$

cells. The difference in cross sectional width may be due to variety differences and/or

stalk position.
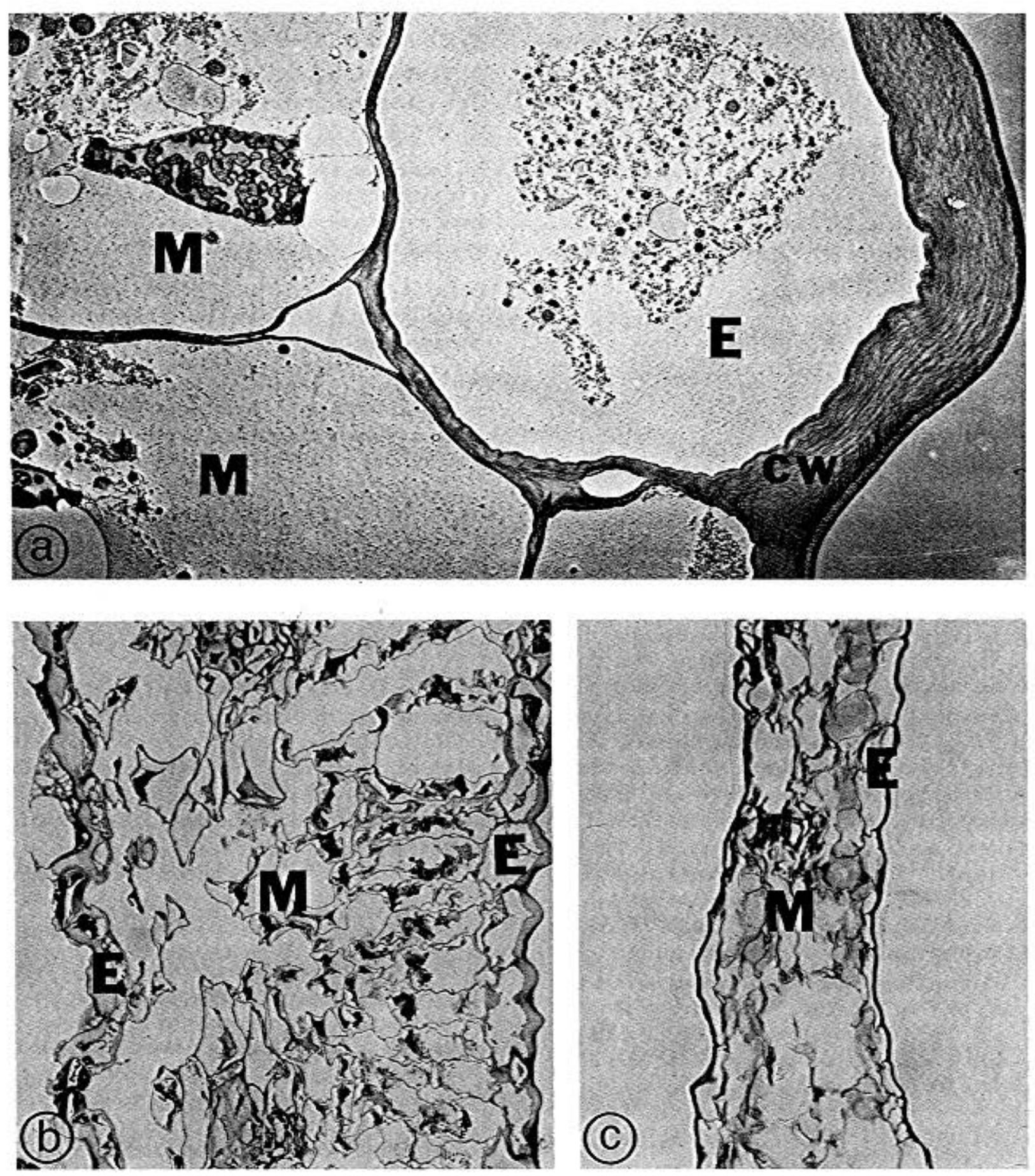
(a): Bright,
transmission electron microscopy, magnified by 2000 .
(): Bright, light microscopy, magnified by 340 .
(c): Burley.
Eght microscopy, magnified by 340 .

Cw: cell wall
- middle lamella
- Mesophyll cells include borh spongy and palisade cells. 
Figure 2.

Water-extracted samples. Note well-defined epidermal $(E)$ cell walls and the partial col-

lapse of the mesophyll (M) cells. The percentage of the total calcium removed was $43 \%$ in

Bright and $47 \%$ in Burley.
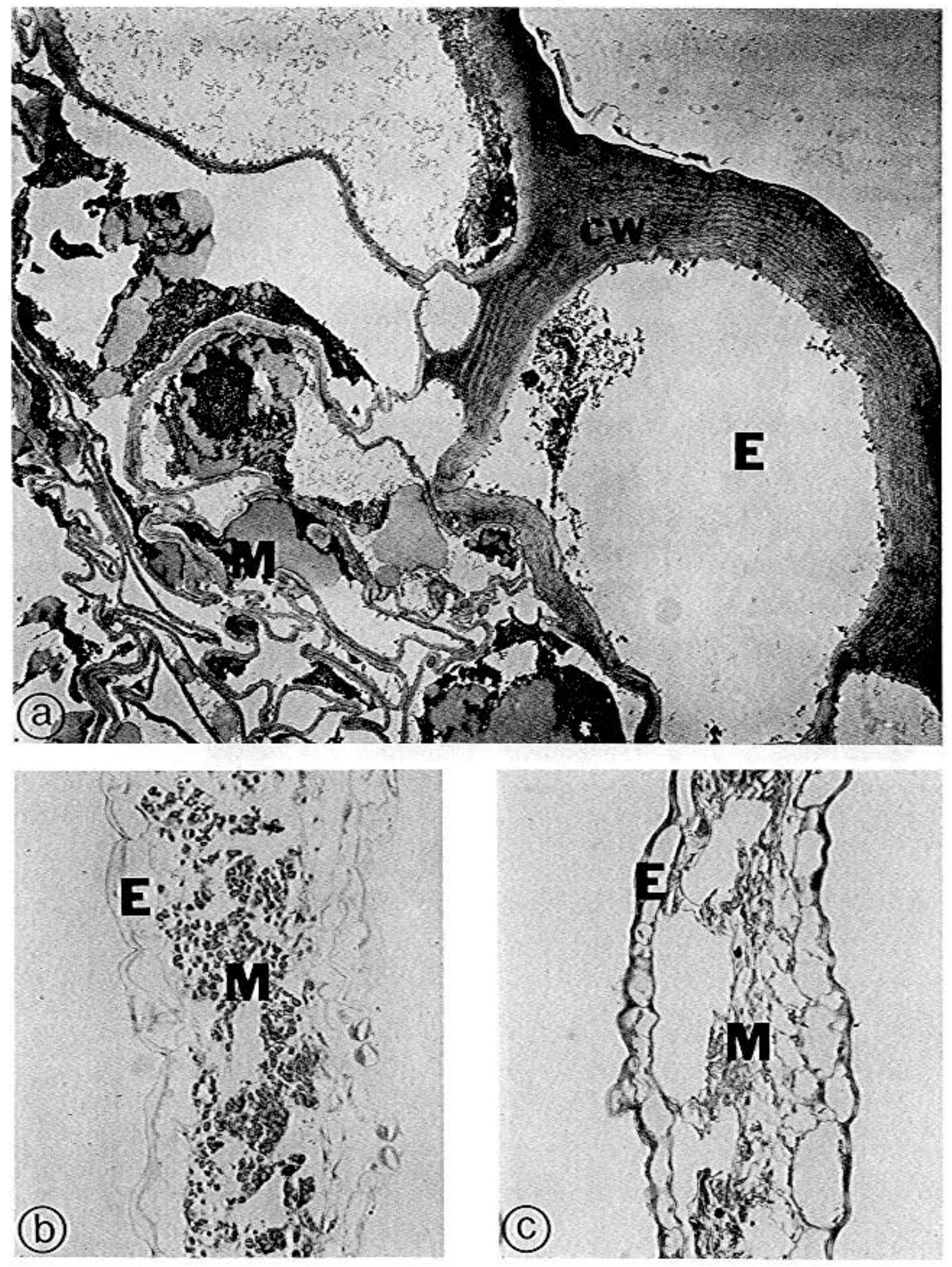

(a): Buriey,

(b): Exight:

magnified by 2600 .

light microscopy, magnitied by 340 .

(C): Burley,

light microscopy, magnified by 340 .

cw: cell wall 
Figure 3.

Samples extracted with water and potassium chloride. The epidermal cells (E) were intact in the Bright sample but were beginning to bend in the Burley shred. Note the collapse of the mesophyll cells $(\mathrm{M})$ and the open structure of the lignified vascular bundle. The per-

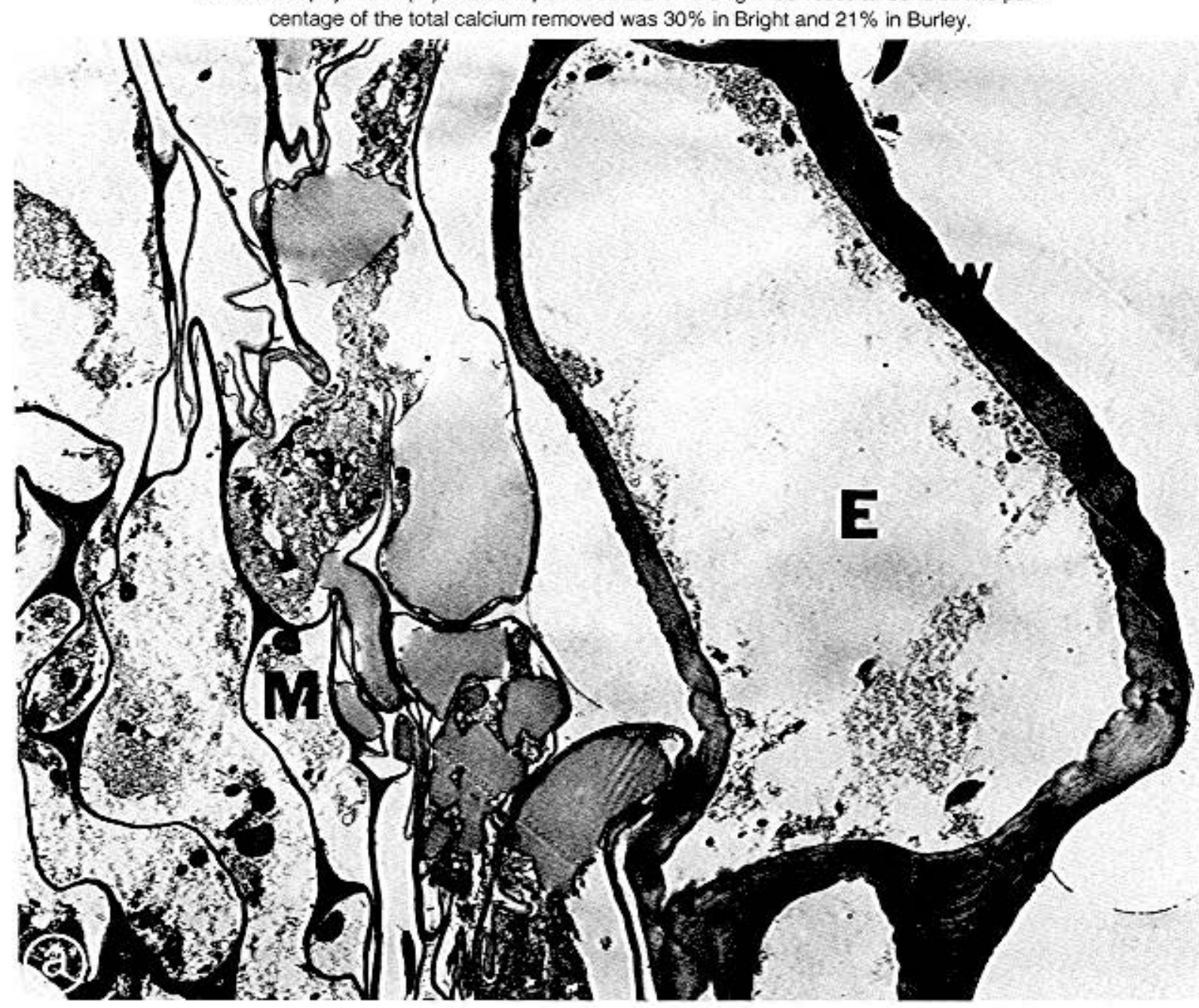

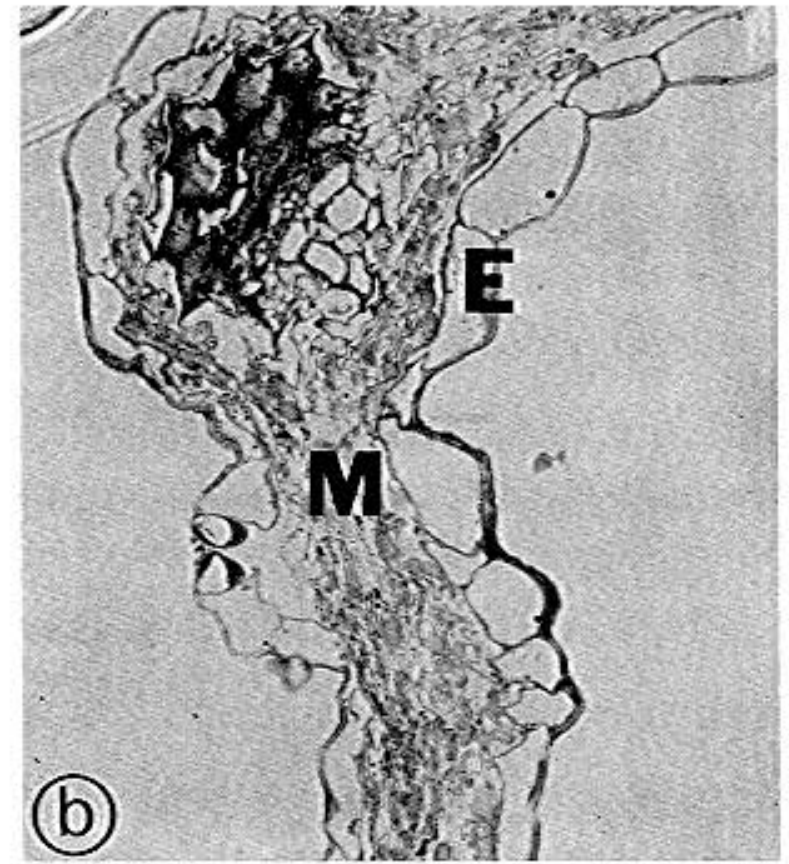

(a): Burley,

transmission electron microscopy, magnified by 2600 (b): Bright,

light microscopy, magnified by 340 .

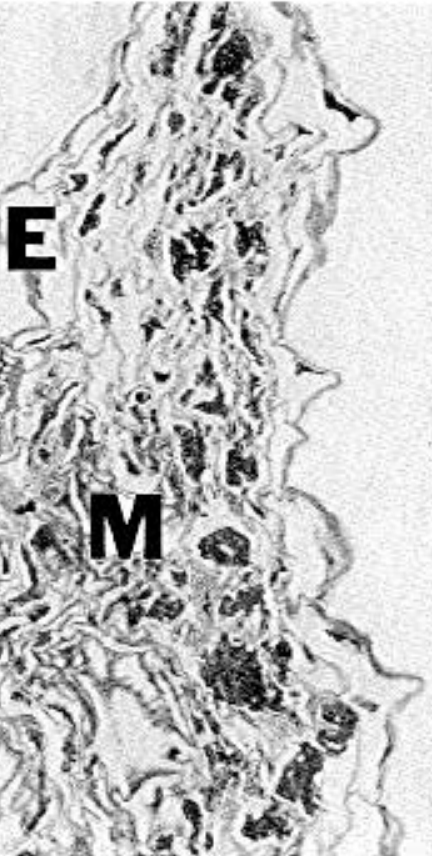

(C): Burley,

light microscopy, magnified by 340 . 
Figure 4. Samples extracted with water, potassium chioride and lanthanum chloride. The epidermal $(E)$ and mesophyll ( $M$ ) cels collapsed. The percentage of the total calcium removed in this step was $20 \%$ for Bright and $23 \%$ for Burley. Note the partial separation of cell walls at arrow and the apparent disorganization of the cellulose in the epidermal cell walls.
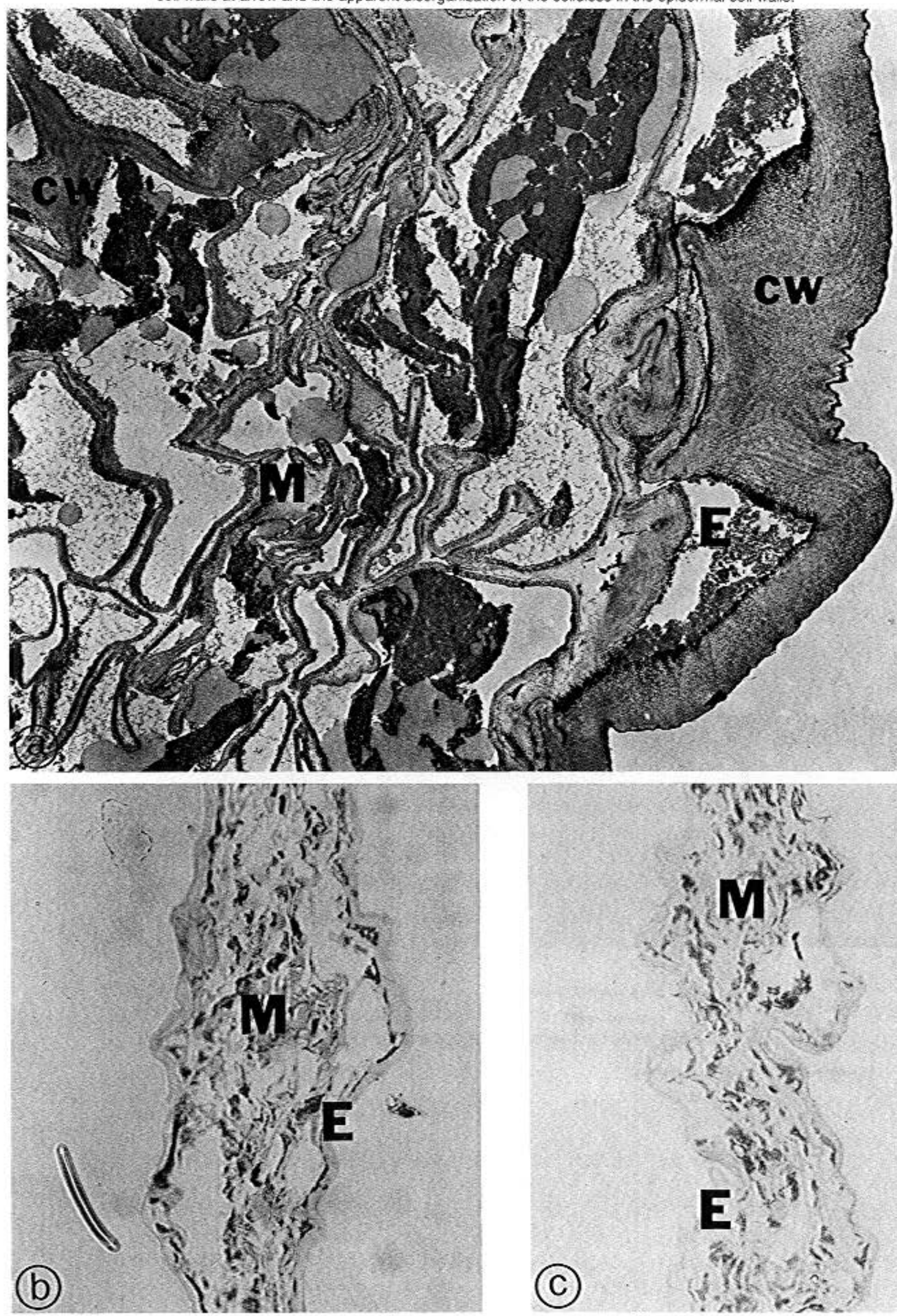

(a): Burley,

(b): Bright,

transmission electron microscopy, magnified by 2600 . 
Figure 5.

Samples extracted with water, potassium chloride and lanthanum chloride. X-ray dot map of lanthanum (La) was associated with the electron dense area within the cell walls.

The heavier concentration of dots represents the lanthanum accumulation.

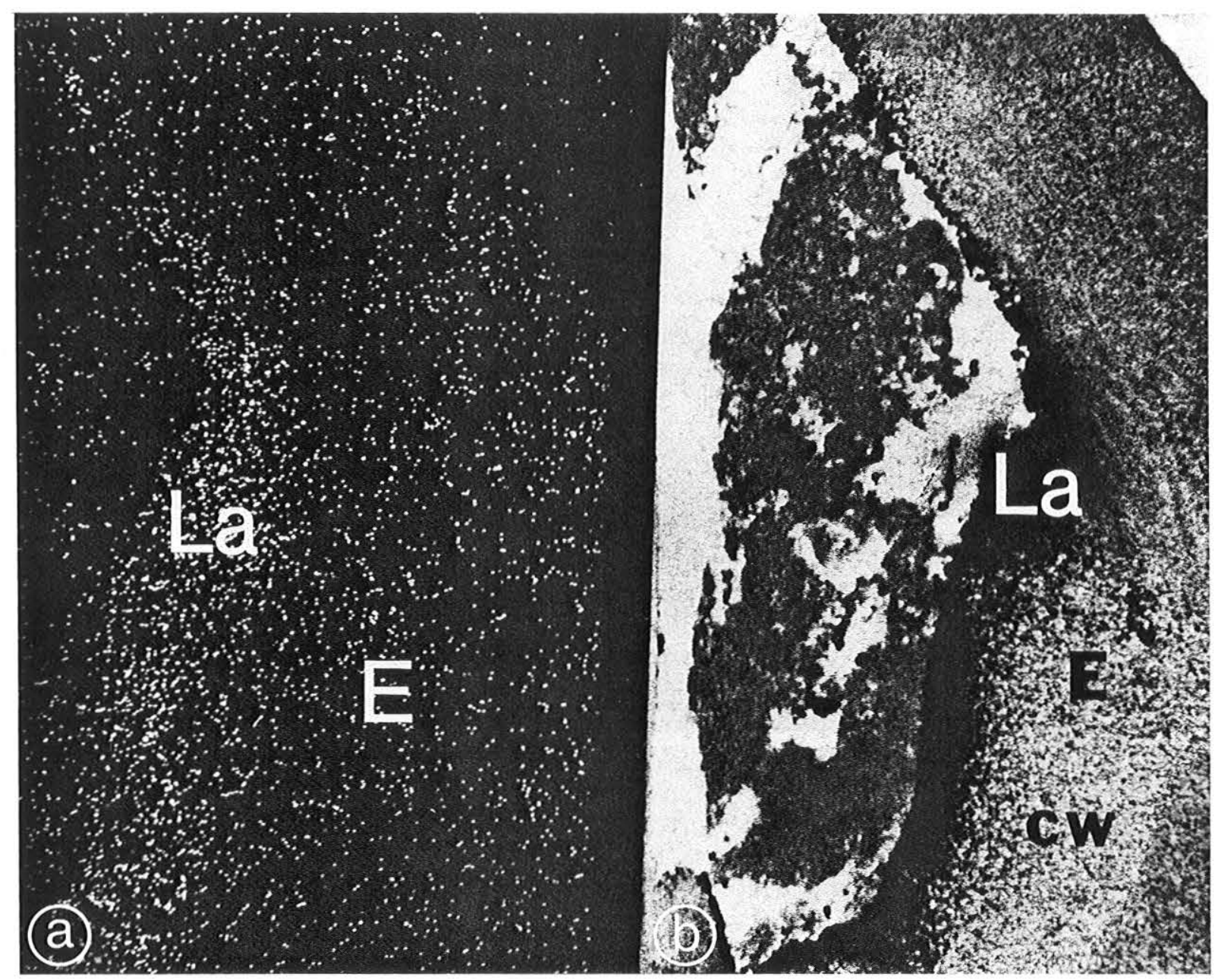

(a): X-ray map of lanthanum.

(b): Epidermal cell wall of Burley shred with lanthanum accumulation, scanning transmission electron microscopy, magnified by 12000 .

cw: cell wall 
Table 1.

Percentage of total calclum removed after each extraction.

\begin{tabular}{l|c|c}
\hline \multirow{2}{*}{$\begin{array}{l}\text { Sequential } \\
\text { extraction steps }\end{array}$} & \multicolumn{2}{|c}{$\begin{array}{c}\text { Percentage of } \\
\text { total calcium removed }\end{array}$} \\
\cline { 2 - 3 } & Bright & Burley \\
\hline $\mathrm{H}_{2} \mathrm{O}$ & 43 & 47 \\
$\mathrm{KCl}(0.4 \%)$ & 30 & 21 \\
$\mathrm{LaCl}_{3}(0.4 \%)$ & 20 & 23 \\
$\mathrm{HCl}(2 \%)$ & 7 & 9 \\
\hline
\end{tabular}

There was no significant calcium remaining in the extracted residue.

ric open form with well-defined primary cell walls and an intact middle lamella. The tobacco structure after water extraction is shown in Figure 2. The mesophyll was partially collapsed in both tobacco types, but the epidermal cell walls maintained their open form and structural integrity. The adjacent primary cell walls were closely attached, indicating very little loss of calcium from pectin in the middle lamella.

The percentages of total calcium removed from Bright and Burley tobacco shreds after water extraction were $43 \%$ and $47 \%$, respectively, as shown in Table 1 . In Bright tobacco, $47 \%$ of the dry weight was lost which includes reducing sugars, organic acids, and soluble inorganics. The partial collapse of the mesophyll cell walls may be the result of a combined effect of the above events. Sequential extraction with water shows that a specific amount of calcium is removed during the first extraction and that no more is removed with subsequent extraction.

In the water and potassium chloride - extracted shreds (Figure 3) the mesophyll cells exhibited a variable degree of collapse. The epidermal cells of Bright tobacco still maintained an open form. However, the Burley tobacco showed bending of the epidermal cell walls with apparent loss of its structural integrity. The vascular areas in both tobacco types demonstrated an open geometric framework. The ultrastructure of the primary cell walls and the middle lamella were nearly identical to the water-extracted sample. The percentages of total calcium removed after the $\mathrm{KCl}$ extraction for Bright and Burley were $30 \%$ and $21 \%$ respectively with only $3 \%$ additional weight loss in Bright tobacco.

In the water, potassium chloride and lanthanum chloride - extracted shreds (Figure 4), both the mesophyll and the epidermal cells were collapsed. There was also separation of the primary cell walls at the middle lamella. This suggested that $\mathrm{Ca}^{2+}$ was removed from the calcium pectate by the lanthanum which preferentially replaces $\mathrm{Ca}^{2+}$ (11). Since all of the water-soluble $\mathrm{Ca}^{2+}$ had been removed by the two previous extraction steps the calcium removed by the lanthanum chloride was assumed to be structural calcium. Cell wall separation at this step would be expected to occur as illustrated in Figure 4.
Table 2.

Amounts of calclum and oxalate removed during each extraction step ( $\mu$ moles per gram of Bright tobacco).

\begin{tabular}{l|c|c|c|c}
\hline $\begin{array}{c}\text { Sequential } \\
\text { extraction } \\
\text { steps }\end{array}$ & Oxalate & $\begin{array}{c}\text { Calcium } \\
\text { as } \\
\text { oxalate* } \\
(\mu \mathrm{mol})\end{array}$ & $\begin{array}{c}\text { Non- } \\
\text { oxalate } \\
\text { calcium } \\
(\mu \mathrm{mol})\end{array}$ & $\begin{array}{c}\text { Total } \\
\text { calcium } \\
(\mu \mathrm{mol})\end{array}$ \\
\hline $\mathrm{H}_{2} \mathrm{O}$ & 10 & 10 & 128 & 138 \\
$\mathrm{KCl}$ & 21 & 21 & 74 & 95 \\
$\mathrm{LaCl}_{3}$ & 19 & 19 & 49 & 68 \\
$\mathrm{HCl}$ & 38 & 38 & -3 & 35 \\
Total & 88 & 88 & 248 & 336 \\
\hline
\end{tabular}

"The values of these columns are calculated.

Lanthanum is a heavy metal and is electron dense which makes it a useful marker for transmission electron microscopy. The electron dense material within the cell walls was identified as containing lanthanum by an X-ray map of lanthanum which is shown in Figure 5. Lanthanum is believed to have replaced the calcium in the primary cell wall, secondary cell wall and in the middle lamella. The percentages of total calcium removed from the Bright and Burley shreds after $\mathrm{LaCl}_{3}$ extraction were $20 \%$ and $23 \%$ respectively of the total calcium with only another $1.5 \%$ weight loss in Bright tobacco.

The final extraction of the tobacco shreds with $2 \%$ $\mathrm{HCl}$ caused a total deterioration of the epidermal and mesophyll cells as shown in Figure 6. The cell walls appeared to have lost all structural integrity. The cellulose fibers in the primary cell walls appeared to have separated in some areas. Portions of the middle lamella also showed signs of deterioration. In some areas the structurally oriented middle lamella had separated into a random fibrous mesh. Seven percent and nine percent of the total calcium were extracted from the Bright and Burley respectively, with an additional weight loss of $7.5 \%$ in Bright tobacco. $\mathrm{HCl}$ extraction dissolved the calcium oxalate and also extracted much of the lanthanum. It would be difficult to say that the total collapse of the cellular architecture was because of calcium removed by $\mathrm{HCl}$ since the effect of $2 \% \mathrm{HCl}$ is not limited to calcium extraction alone.

Ferguson et al. (2) observed that the nature of the plant material and the imprecise nature of many forms of calcium with their varying solubilities precluded the separation of specific forms of calcium by a single solvent. They showed that $\mathrm{HCl}$ was a very good solvent for calcium oxalate and that for some plant material prior extraction with water, salt solutions, and acetic acid did not dissolve any calcium oxalate. For other plant material water removed a significant portion of the total calcium oxalate present.

Table 2 shows: [1] the amounts of oxalate removed by the series of solvents, [2] the corresponding calcium values, if the oxalate extracted is calcium oxalate, [3] the residual non-oxalate calcium, and [4] the total calcium for Bright tobacco. Water, potassium chloride 
Figure 6 .

Samples extracted with water, potasslum chloride, lanthanum chloride and hydrochloric acid. The epidermal $(E)$ and mesophyll $(M)$ cells were totally collapsed with a complete loss of cellular structure. The cellulose and middle lamella were loosely organized. Most of the lanthanum was removed leaving behind a few scattered electron dense areas. The percentage of total calcium removed in this step was $2 \%$ for Bright and $9 \%$ for Burley.
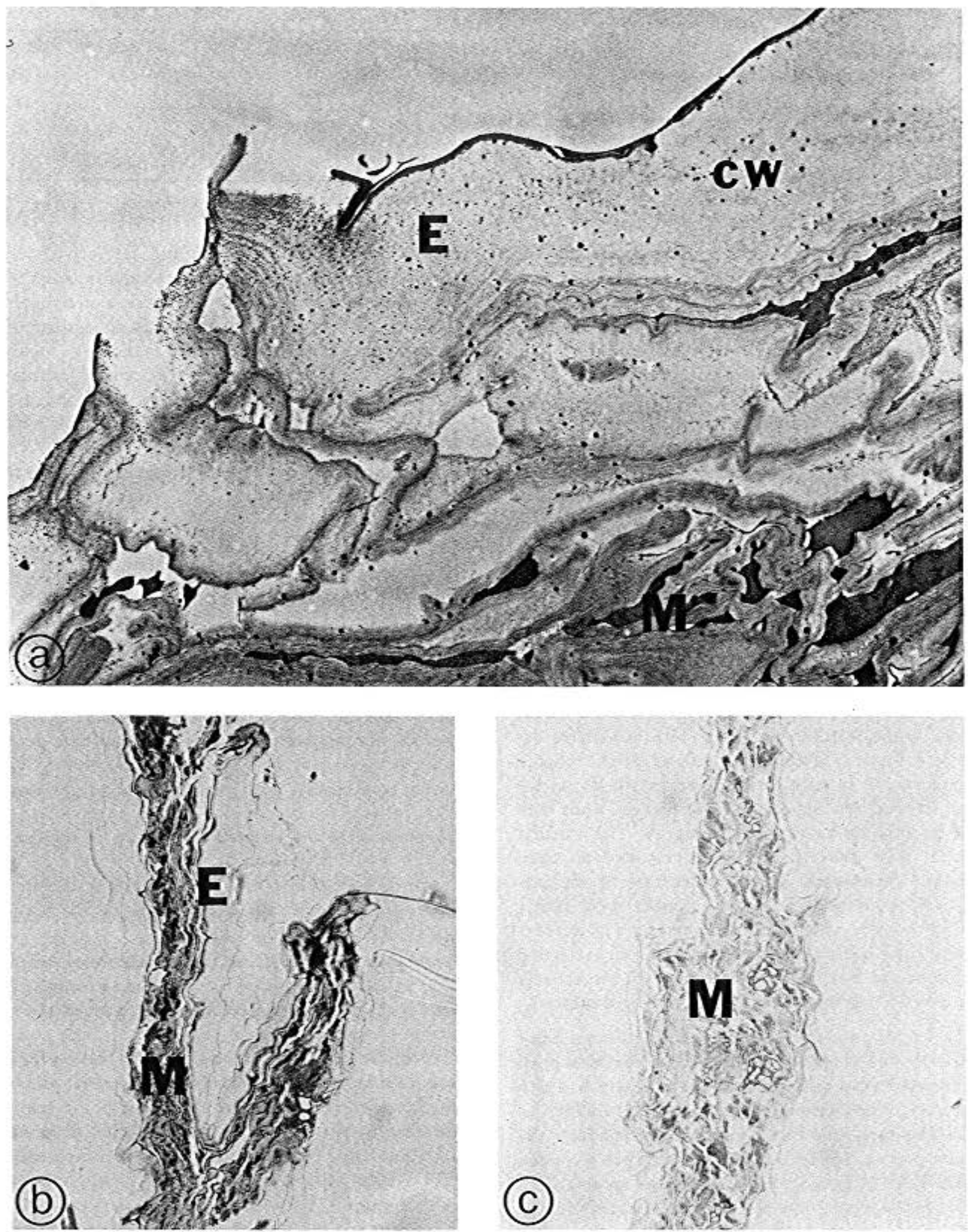

(a): Burley,

transmission electron microscopy, magnified by 5200 .

(b). Bright,

light microscopy, magnified by 340 .

(C): Burley,

light microscopy, magnified by 340 .

cw: cell wall 
and lanthanum chloride each extract oxalate and calcium. However, for the $\mathrm{HCl}$ extraction the amounts of oxalate and calcium are stoichiometrically equivalent and thus it may be assumed that only calcium oxalate is extracted in this step. These data support Ferguson's observation on Ca solubility; however, the microscopy data strongly support the fact that the calcium associated with pectin is removed during the lanthanum chloride extraction. Studies of uronic acid residues are in progress to support these observations.

These data show that approximately $20 \%$ of the calcium in Bright and Burley tobacco is structurally related (cross-linked to pectin) and that calcium oxalate utilizes another $20 \%$ of the total calcium. The remaining $60 \%$ is non-structural and non-oxalate and is probably inorganic salts and salts of organic acids. If we assume that all of the oxalate present in tobacco is calcium oxalate, then its solubility is not solvent specific as suggested by Ferguson (2). Water-soluble organic acids probably play a large role in rendering some of the calcium oxalate water soluble.

These data also show that by coupling sequential solvent extraction procedures with light microscopy and transmission electron microscopy techniques, we can obtain information relating to the distribution of calcium species. Either technique used independently could not provide the quantitative information obtained from the combined use of both. It is also shown that the extraction sequence, while not specific for calcium alone, is selective for the removal of structural calcium.

These data on extracted leaf help to provide a greater understanding of the role calcium plays in the structural support of the tobacco cell wall. The techniques used in this study are applicable to the investigation of other plant types and may be useful in furthering the general knowledge of the role of calcium in plant materials.

\section{REFERENCES}

1. Faust, M., C. B.' Shear and C. B. Smith: Investigations of corking disorders of apples, II. Chemical composition of affected tissues; Proc. Am. Soc. Hortic. Sci. 92 (1968) 82-88.

2. Ferguson, I. B., N. A. Turner and E. G. Bollard: Problems in fractionating calcium in plant tissue; J. Sci. Food Agric. 31 (1980) 7-14.

3. Gallaher, R. N., and J. B. Jones, Jr.: Total, extractable, and oxalate calcium and other elements in normal and mouse ear pecan tree tissues; J. Am. Soc. Hortic. Sci, 101 (1976) 692-696.

4. Gallaher, R. N., H. F. Perkins and J. B. Jones, Jr.: Calcium concentration and distribution in healthy and decline peach tree tissues; Hort. Science U.S.A. 10 (1975) 134-137.

5. Gallaher, R. N.: Occurrence of calcium in plant tissue as crystals of calcium oxalate; Commun. Soil Sci. Plant Anal. 6 (1975) 315-330.

6. Greene, D. W., and M. J. Bukovac: Redistribution of calcium in Phaseolus vulgaris L.: Proc. Am. Soc. Hortic. Sci. 93 (1968) 368-378.

7. Harvey, W. R., R. W. Hale and R. M. lkeda: The determination of organic acids in plants and food products; Tob. Sci. 14 (1970) 141-144.

8. Kawabata, A., S. Sawayama, H. Nakahara and T. Kamata: Mechanism of association of various demethylated pectins by calcium ions; Agric. Biol. Chem. 45 (1981) 965-973.

9. Konishi, S., and Z. Kasai: Calcium metabolism in the aging process of tobacco leaves, I. Metabolism of $\mathrm{Ca}$ absorbed at each stage of growth; Nippon Dojo - Hiryogaku Zasshi 34 (1963) 67-70.

10. Konishi, S., and Z. Kasai: Calcium metabolism in the aging process of tobacco leaves, II. Metabolism of ${ }^{15} \mathrm{Ca}$ absorbed at the early and the flowering stages of growth; Nippon Dojo - Hiryogaku Zasshi 34 (1963) 71-74.

11. Martin, R. B., and F. S. Richardson: Lanthanides as probes for calcium in biological systems; $Q$. Rev. Biophys. 12 (1979) 181-209.

12. Millonig, G.: Advantages of a phosphate buffer for $\mathrm{OsO}_{4}$ solutions in fixation; J. Appl. Phys. 32 (1961) 1637.

13. Morgan, W. R.: unpublished results.

14. Nosseir, M. A.: Distribution and reutilization of calcium in plants; Adv. Front. Plant Sci. 15 (1966) 137-148.

15. Rasmussen, H. P.: What holds leaf cells together; Front. Plant Sci. 19 (1966) 4-5.

16. Wyn Jones, R. G., and O. R. Lunt: The function of calcium in plants; Bot. Rev. 33 (1967) 407-426.

\section{Acknowledgments}

We want to thank Roger Comes and Lawra McCray for their excellent suggestions and extend special thanks to Mrs. Anne Donathan for ber belp in typing the manuscript.

Authors' address:

Philip Morris Research Center,

P.O. Box 26583,

Ricbmond, Va., 23261, U.S.A. 